\title{
Collet-Sicard Syndrome due to Glomus Jugulotympanicum: Case Report
}

Shiv Parshad Mittal ${ }^{1 *}$, Kiran Kumar Singal ${ }^{2}$, Nitish Thakur ${ }^{3}$, Jaspreet Singh $^{4}$, Yoginder Singh Gulati ${ }^{5}$, Ajinkya Murudkar ${ }^{6}$

${ }^{1}$ Associate Professor, Department of Medicine, MM Medical College \& Hospital Kumarhatti - Solan; Himachal Pardesh, India

${ }^{2}$ Professor, Department of Medicine, MM Medical College \& Hospital Kumarhatti-Solan; Himachal Pardesh, India

${ }^{3}$ Assistant Professor, Department of Medicine, MM Medical College \& Hospital Kumarhatti-Solan; Himachal Pardesh, India

${ }^{4}$ Senior Resident, Department of Radiology, MM Medical College \& Hospital Kumarhatti-Solan; Himachal Pardesh, India

${ }^{5}$ Professor, Department of Radiology, MM Medical College \& Hospital Kumarhatti-Solan; Himachal Pardesh, India

${ }^{6}$ Resident, Department of Medicine, MM Medical College \& Hospital Kumarhatti - Solan; Himachal Pardesh, India

DOI: $10.36347 /$ sjmcr.2020.v08i11.009

| Received: 05.11.2020 | Accepted: 16.11.2020 | Published: 19.11.2020

*Corresponding author: Dr. Shiv Parshad Mittal

\section{Abstract}

Collet-Sicard syndrome (CSS) is a clinical condition due to lesions at skull base involving both jugular foramen and hypoglossal canal, and affecting lower cranial nerves i.e. IX, X, XI and XII. We report a case of Collet-Sicard syndrome, in an elderly lady, caused by intracranial tumor Glomus jugulotympanicum.

Keywords: Globus jugulotympanicum, Collet-Sicard Syndrome, lower cranial nerves.

Copyright $($ C 2020 The Author(s): This is an open-access article distributed under the terms of the Creative Commons Attribution 4.0 International License (CC BY-NC 4.0) which permits unrestricted use, distribution, and reproduction in any medium for non-commercial use provided the original author and source are credited.

\section{INTRODUCTION}

Collet in 1915 and Sicard in 1917 described this syndrome, but named it as "glossolaryngoscapulopharyngeal hemiplegia" and "syndrome of the condyloposterior lacerated foramen", respectively [1, 2]. It is a rare syndrome caused by heterogeneous lesions involving the base of skull e.g. tumors at jugular foramen [3], infectious condition [3], fracture of first cervical vertebra (Jefferson fracture) [4], metastasis [5], Internal Carotid artery dissection [8]. In CSS, lower cranial nerves i.e. IX, X, XI, and XII, usually of one side, are involved with lower motor neuron type paralysis, as these cranial nerves run through the jugular foramen (IX, X, XI ) or through the hypoglossal foramen (XII) at the base of skull.

\section{CASE REPORT}

An elderly lady (age 75 years) reported in this territory medical Hospital with history of gradually increasing difficulty in swallowing, speaking, and tinnitus and pain left ear for 2 months. Three weeks prior to hospitalization, she developed nasal regurgitation and nasal twang, inability to protrude tongue or move it on left side producing dysphasia and dysphonia, and unable to shrug left shoulder and turn neck to right.
She did not have headache, visual symptoms, altered behavior, sphincter incontinence or weakness in limbs, or symptoms of infection. No past history of tuberculosis, diabetes mellitus, hypertension or cerebrovascular accident.

\section{On Examination}

Patient was conscious, emaciated, and not dyspneic at rest. She followed gestures, could not speak. She was normotensive. ENT examination: pulsatile movements of left tympanic membrane, and pooling of saliva in pyriform fossae. Larynx and vocal cords were normal. CNS examination revealed lower motor neuron paralysis of left IX, X, XI and XII cranial nerves. Uvula was deviated to right, and no atrophy or fasciculation of tongue. Grade II muscle power of left trapezius and sternocleidomastoid muscles was present. Other aspects of central nervous system examination, including cerebellum, were normal. She had no meningitis.

Routine hematological, biochemical parameters, and urinalysis were normal. CEMRI brain (Fig-1) revealed ill-defined altered soft tissue signal intensity lesion in the left jugular fossa. 


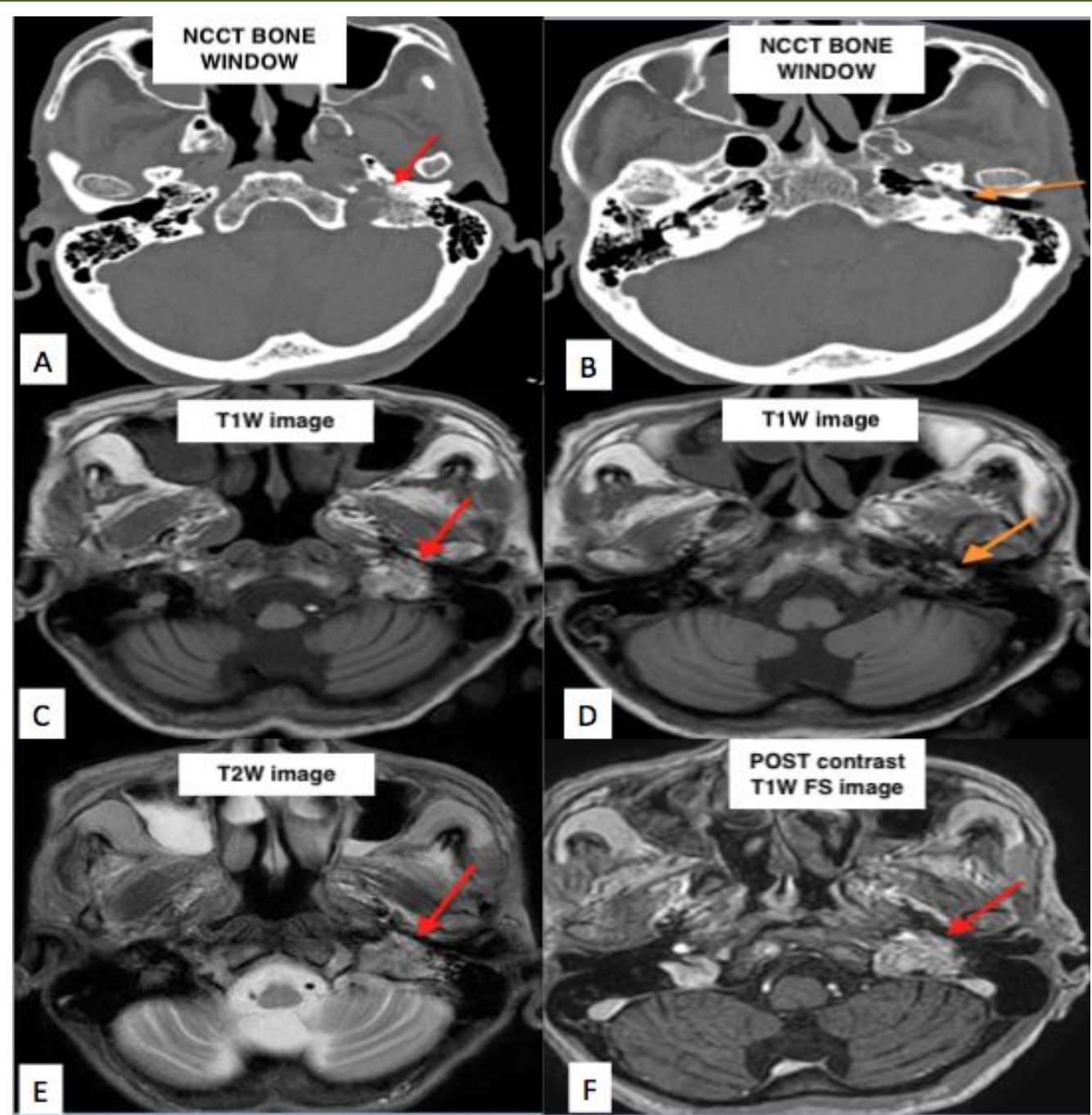

Fig-1: A \& B shows an ill-defined soft tissue density lesion in the left jugular foramen causing erosions (red arrow) in the petrous part of temporal bone. A soft tissue density (orange arrow) is also noted in the left middle ear cavity anterior to the cochlear promontory (B \& D). On MR images appear hyperintense on both T1W (C) \& T2W (E) images with hypointense foci (likely flow voids) on post contrast images (F) it shows intense enhancement) causing its widening and it was extending along upper part of jugular vein in carotid space.

There were erosions of jugular fossa, jugulotympanic wall, and widening along with soft tissue in the middle ear cavity, suggestive of left sided glomus jugulotympanicum. It also revealed saccular aneurysm at the junction of M1 \& M2 segment of right middle carotid artery of 6(CC) X 5(TR) X 6(AP) mm pointing superolaterally.

CEMRI cervical spine revealed marked cervical spondylosis changes in $\mathrm{C} 3$ to $\mathrm{C} 7$ vertebrae. $\mathrm{X}$ Ray chest and X-Ray jugular foramen were normal. X left mastoid bone showed sclerosis of some air cells with irregular bone margins.

\section{DISCUSSION}

Collet-Sicard syndrome (CSS) is a rare condition, described in the literature as case reports only. Causes of CSS are heterogenous [7]:

(a) Tumors: Jugular glomus tumor, nurinoma hypoglossus, multiple myeloma

(b) Vascular: Internal carotid artery aneurysm / dissection. Internal jugular vein thrombosis (c) Infection: Osteomyelitis

(d) Non-infectious Inflammatory: Polyarteritis nodosa

(e) Trauma: Fracture of C1 (Jefferson's fracture), base of skull

(f) Skull Metastasis: Breast, Prostate, colon, kidney, uterus / cervix

Our patient presented with gradually increasing lower motor neuron paralysis of left IX, X, XI and XII cranial nerves, was caused by glomus jugulotympanicum (paraganglionoma). Being a highly vascular tumor, it has produced a pulsatile left tympanic membrane. The tumor had also expanded into the cranial fossa and involved lower cranial nerves described above. There may be facial palsy or hearing loss in large globus tympanicum tumor [6]. Our patient had no facial palsy or hearing loss.

\section{Conclusion}

Globus jugulotympanicum being a rare cause of CSS, hence it necessitated us to present this case. 


\section{REFERENCES}

1. Collet FJ. Sur un nouveau syndrome paralytique pharyngo-laryngé par blessure de guerre. Lyon Med. 1915;124:121-9.

2. Sicard JA. Syndrome du carrefour condylodechire posterieur (type pur de paralysie des quatre derniers nerfs craniens). Mars Med. 1917;53:38597.

3. Gutiérrez Rios R, Castrillo Sanz A, Gil Polo C, Zamora García MI, Morollón Sánchez-Mateos N, Mendoza Rodríguez A. Síndrome de ColletSicard. Neurología. 2015;30(2):130-2.

4. Kwon HC, Cho DK, Jang YY, Lee SJ, Hyun JK, Kim TU. Collet-sicard syndrome in a patient with jefferson fracture. Annals of Rehabilitation Medicine. 2011 Dec;35(6):934-938.

5. Chacon G, Alexandraki I, Palacio C. Collet-Sicard syndrome: an uncommon manifestation of metastatic prostate cancer. Southern medical journal. 2006 Aug 1;99(8):898-900.

6. Appannan VR, Daud MK. Glomus tympanicum. Malays Fam Physician. Apr 2018;13(1):45-48.

7. de Oliveira IA, Cordeiro BM, Coelho RD, de Sousa AF, Barros YC. Collet-Sicard syndrome: Case report. J Exp Med Biol. 2019;1(1):16-18.

8. Smith R, Tassone P, Saada J. Collet-Sicard syndrome as a result of unilateral carotid artery dissection. Case Reports. 2013 Jul 31;2013:bcr2013200358. 